\title{
A new species of Vriesea Lindl. (Bromeliaceae, Tillandsioideae) from serra da Canastra, Minas Gerais State, Brazil
}

\author{
Leonardo M. Versieux ${ }^{1,2,3}$ and Maria das Graças Lapa Wanderley ${ }^{2}$
}

Received: October 26, 2006. Accepted: May 2, 2007

\begin{abstract}
RESUMO - (Nova espécie de Vriesea Lindl. (Bromeliaceae, Tillandsioideae) da serra da Canastra, MG, Brasil). Uma nova espécie de Vriesea Lindl. pertencente à seção Xiphion (E. Morren) E. Morren ex Mez - V. sanfranciscana Versieux \& Wand. - é descrita e ilustrada. A espécie só é conhecida do Parque Nacional da Serra da Canastra, localizado no sudoeste de Minas Gerais, Brasil, e relaciona-se morfologicamente com V. atropurpurea Silveira, da serra do Cipó, serra do Espinhaço.
\end{abstract}

Palavras-chave: Bromeliaceae, Tillandsioideae, Vriesea, Minas Gerais, serra da Canastra

ABSTRACT - (A new species of Vriesea Lindl. (Bromeliaceae, Tillandsioideae) from serra da Canastra, Minas Gerais State, Brazil). A new species of Vriesea Lindl. belonging to section Xiphion (E. Morren) E. Morren ex Mez. - V. sanfranciscana Versieux \& Wand.- is described and illustrated. The species is only known to occur in the Serra da Canastra National Park, located in the southwestern Minas Gerais, Brazil, and is morphologically related to V. atropurpurea Silveira from serra do Cipó, Espinhaço range.

Key words: Bromeliaceae, Tillandsioideae, Vriesea, Minas Gerais, serra da Canastra

\section{Introduction}

The Parque Nacional da Serra da Canastra (PNSC) is located in southwestern Minas Gerais (MG) and presents a flora rich in cases of restricted endemism (Romero \& Nakajima 1999). In the checklist of the Bromeliaceae of MG, Versieux \& Wendt (2006; 2007) identified one taxon as Vriesea sp.1 related to Vriesea atropurpurea Silveira. After examining collections of $V$. atropurpurea recently obtained in its type locality region - Santana do Riacho, Parque Nacional da Serra do Cipó, Wanderley et al. 2491, 2492 and Versieux et al. 296, 297 (SP, SPF) - we were able to recognize that $V$. sp. 1 is a distinct taxon so far restricted to serra da Canastra.

\section{Description and discussion}

Vriesea sanfranciscana Versieux \& Wand., sp. nov. Fig. 1-2

Vrieseae atropurpureae Silveira, affinis, sed laminis foliorum brevioribus, latioribus, apiculatis, bracteis florum lepidotis, patentibus sub anthesi, decurrentibus, auriculatis, internodiis inflorescentiarum insigniter nervatis, floribus majoribus differt.

Plant rupicolous or terricolous, heliophyte, flowering $0,8-1,5 \mathrm{~m}$ tall. Leaf sheaths broadly elliptic, $12-16 \times 10,5-12 \mathrm{~cm}$, dark castaneous in the base, pale castaneous toward apex, densely brown lepidote in both surfaces. Blades ligulate, apex rounded and mucronate, (10)20-28×(5,5)8-9 cm, green, concolorous, chartaceous, densely pale brown lepidote abaxially and in lower density adaxially. Scape green, ca. $0,7 \mathrm{~m}$ long, $1 \mathrm{~cm}$ diam. in the base, $6-8 \mathrm{~mm}$ diam. in the middle, distinctly nerved, glabrescent or sparsely brown lepidote, terete, internodes 3-5,5 cm; scape bracts: the proximal ones subfoliaceous and suberect, the distal ones narrowly ovate, apex acute and apiculate, 4-7×2,5-3 $\mathrm{cm}$, green, densely brown lepidote in both surfaces, completely concealing the basal $1 / 2$-portion of the internode and exceeding them in lengh, erect, imbricate, chartaceous. Inflorescence simple, linear to lanceolate, 21-33×9-13 cm (excluding the petals), 17-to 25flowered; rachis distinctly nerved, slightly angulose, almost quadrangular in cross section, brown lepidote; internodes $(0,8) 1,1-2 \mathrm{~cm}$; floral bracts broadly ovate to suborbicular, bearing in the base two auricles decurrent

\footnotetext{
Departamento de Botânica, IB, Universidade de São Paulo, São Paulo, SP, Brasil

2 Instituto de Botânica, C. Postal 3005, 01061-970, São Paulo, SP, Brasil

3 Corresponding Author: lversieux@yahoo.com.br
} 


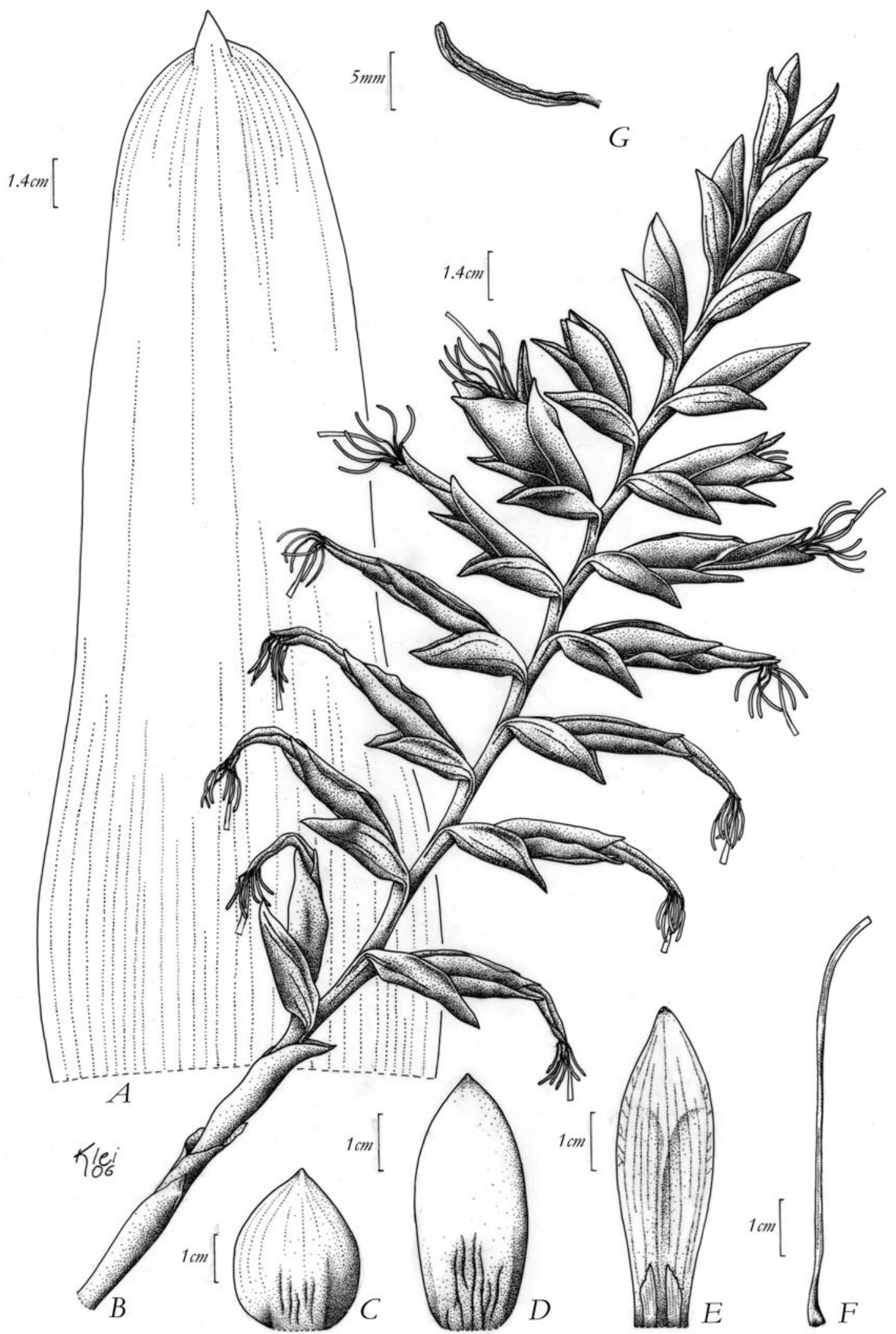

Figure 1. Vriesea sanfranciscana Versieux \& Wand. A. Leaf. B. Inflorescence. C. Floral bract. D. Sepal. E. Petal. F. Gynoecium. G. Anther and connective (dorsal view). (From the holotype). 
with the rachis, apex with a recurved mucro, $3,2-5,2 \times(2,2-) 2,7-3 \mathrm{~cm}$, green, densely brown lepidote in both surfaces, margins membranaceous and yellowish in the dried material, erect in the flower buds, patent at anthesis, ecarinate; flowers distichous, $6-8 \mathrm{~cm}$, forming an angle of ca. $20^{\circ}$ with the patent floral bracts; pedicels obconic, 9-12×4-6 mm; sepals elliptic, apex acute, 4-4,6×(1-)1,3-1,8 cm, symmetric, green, brown lepidote in both surfaces, ecarinate but with small traces along the carnose base; petals spreading, narrowly obovate, yellow, ca. $6 \times 1,7 \mathrm{~cm}$; petal appendages asymmetric, ca. $12 \times 3 \mathrm{~mm}$, adnate to the petal for ca. $7 \mathrm{~mm}$, apex irregularly lobate; filaments ca. $6,3 \mathrm{~cm}$; anthers exserted, linear to falciform, ca. $16 \times 2 \mathrm{~mm}$, dorsifixed near the base; style terete ca. $8,2 \mathrm{~cm}$. Ovary ovate, $9 \times 5 \mathrm{~mm}$; ovules numerous, ca. $1 \mathrm{~mm}$.

Type: BRASIL. Minas Gerais: São Roque de Minas, Parque Nacional da Serra da Canastra, Estrada para Sacramento, Curral de Pedras, fl., 11/I/1995, R. Romero, J.N. Nakajima \& D.G. Simão 1717. (Holotype SP, Isotype: HUFU).

Paratypes: BRASIL. Minas Gerais: São Roque de Minas, Parque Nacional da Serra da Canastra, morro próximo à sede administrativa, fl., 17/III/1995, R. Romero, J.N. Nakajima, E. Zanini \& R. Cesar 1974 (SP, HUFU). Ibidem, ca. $3 \mathrm{~km}$ na estrada para Sacramento, fl., 9/I/1998, R. Romero, J.N. Nakajima \& M.A. Farinaccio 4838 (HUFU, SP).São Roque de Minas, Parque Nacional da Serra da Canastra, fl., 29/XII/1982, C. Farney 182 (RB).

Vriesea sanfranciscana is closely related to $V$. atropurpurea Silveira. However the former species presents lepidote floral bracts with decurrent auricles at the base, larger flowers, a conspicuously nerved and stouter rachis, and a simple inflorescence (vs. simple or compound in $V$. atropurpurea). The leaves are very distinct in $V$. sanfranciscana with ligulate, broader, and green blades (vs. narrowly triangular, smoother, longer, and purplish green toward apex). At anthesis the position of the flowers is very characteristic in $V$. sanfranciscana. The floral bracts keep perpendicular to the rachis while the flowers are suberect, thus flower and floral bract form an angle of ca. $20^{\circ}$. In $V$. atropurpurea both the floral bracts and the flowers become secund toward the apex. The stamens with exerted falciform anthers, the dull green color of the bracts, the obovate petals that form a campanulate corolla, justify the inclusion of this new species in section Xiphion (E. Morren) E. Morren ex Mez.
Though separated by more than $300 \mathrm{~km}$, both species are fairly similar concerning habitat, growing in campo rupestre vegetation. Vriesea sanfranciscana grows as a lithophyte between 1000-1200 m inside Parque Nacional da Serra da Canastra, São Roque de Minas county, southwestern MG, while $V$. atropurpurea grows between $1200-1300 \mathrm{~m}$ as terrestrial in sandy soils and is restricted to a site known as Alto Palácio, close to the top of serra do Cipó, Santana do Riacho county, central portion of MG (Fig. 2). It is important to mention that the recently collected material of $V$. atropurpurea - Wanderley et al. 2491, 2492 and Versieux et al. 296, 297 (SP, SPF) - was identified according to the circunscriptions presented by Silveira (1931), and Leme (1999), since Smith \& Downs (1977: 1232, Plate 403) treated $V$. atropurpurea with a broader concept that includes V. minarum L.B. Sm. as a synonym.

Conservation: This new species is protected inside the PNSC, but conservation measurements may be required to protect its populations from disturbance that may occur (e.g., fires), especially if future collections confirm that Vriesea sanfranciscana is confined only to the area of the PNSC. Considering Romero \& Nakajima's (1999) areas of endemism within the PNSC, V. sanfranciscana occurs in areas 1 (sede administrativa) and 4 (curral de pedras). Both these areas present an elevated endemism and are also type localities for many different new species that have been recently described.

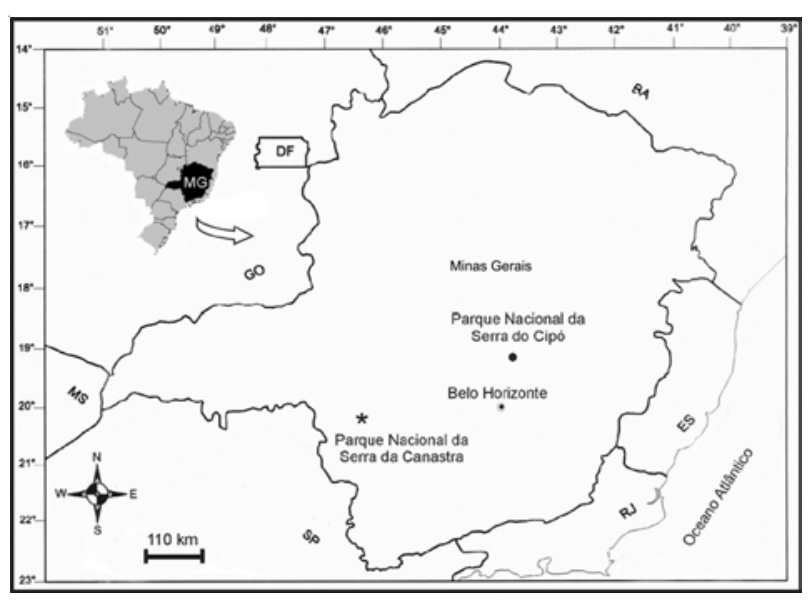

Figure 2. Distribution of Vriesea atropurpurea Silveira in serra do Cipó (black dot) and of $V$. sanfranciscana Versieux \& Wand. in serra da Canastra (asterisk) in Minas Gerais, Brazil. 
Etymology: the species was named after the rio São Francisco, one of the most important and threatened rivers from Brazil, which has its headwaters along the area occupied by the new species.

Flowering time: December to early March.

\section{Acknowledgements}

We acknowledge IBAMA, for authorizing plant collection. Dr. Rosana Romero, for her valuable information on the new species, and Dr. Tarciso Filgueiras for correcting the Latin diagnose. The curators, keepers, and collectors of herbaria HUFU and RB, for loans and access to their collections. The artist/biologist Klei Sousa for the illustration. Financial support was provided by FAPESP to L.M. Versieux and by CNPq to M.G.L. Wanderley.

\section{References}

Leme, E.M.C. 1999. Revision of the lithophytic Vriesea species from Minas Gerais state, Brazil - Part III. Journal of the Bromeliad Society 49: 3-11.

Romero, R. \& Nakajima, J.N. 1999. Espécies endêmicas do Parque Nacional da Serra da Canastra, Minas Gerais. Revista Brasileira de Botânica 22: 259-265.

Silveira, A.A. 1931. Floralia Montium. v. II. Belo Horizonte, Imprensa Official.

Smith, L.B. \& Downs R.J. 1977. Tillandsioideae (Bromeliaceae). Flora Neotropica Monograph 14: 663-1492.

Versieux, L.M. \& Wendt, T. 2006. Checklist of Bromeliaceae of Minas Gerais, Brazil with notes on taxonomy and endemism. Selbyana 27: 107-146.

Versieux, L.M. \& Wendt, T. 2007. Bromeliaceae diversity and conservation in Minas Gerais state, Brazil. Biodiversity and Conservation 16: 2989-3009. 